\title{
ファジィ理論を用いた自律型ロボットの知能部の開発 \\ Development of Command prosessing subsystem of Autonomous Mobile Robot using Fuzzy Theory
}

\author{
○学 野口 豊広 (大同工大院) 正 尾形 和哉（大同工大） \\ Toyohiro NOGUCHI, Graduate student of Daido Institute of Technology \\ Kazuya OGATA, Daido Institute of Technology, 10-3 Takiharu-cyou, Minami-ku, Nagoya \\ Key Words : Fuzzy Theory, Autonomous Mobile Robot, Omunidirectional Vision, RoboCup, Soccer Robot
}

\section{1.はじめに}

近年，人間が細かく教示しなくてもロボット自身が状況 に応じて動く自律型ロボットの研究が盛んに行われている. 本学では, 2004 年から自律型ロボットの競技大会, RoboCup ${ }^{1)}$ サッカー中型リーグに参加している. 実際の試 合において，ロボットを取り巻く状況は常に変化する。 そ の中で周囲の情報を正確に得て対応する処理を If-Then ル ールだけで行うと, プログラムが非常に複雑になる.

このため，曖昧な情報を用いての制御が可能なファジィ 理論などの知的制御手法が積極的に用いられている2).

そこで本研究では，ファジィ理論を応用し，できるだけ プログラムが簡素になるように知能部の開発を行った。 ま た，制御方法を口頭で表現できるというファジィ制御の特 性に注目し，新たにファジィルールを追加する際に，その 効果を評価するための手法の提案を行った。

\section{2.リニアファジィ推論法}

\section{1 代数積加算重心法}

知能部に機能拡張を容易に行えるようにするため，直感 にあった推論結果を得ることが可能な代数積加算重心法を 用い，知能部の作成を行った。この方法の特徽は，1つの ルール行毎に貢献度を設定でき，その結果ファジィの特徴 である多入力の情報変化が全て有効に機能し，後件部が無 視されることもなくなることである.

ルール $\mathrm{k}$ において，入力 $\mathrm{i}$ が $\mathrm{u}_{\mathrm{i}}$ であるとき，ラベル $\mathrm{L}_{\mathrm{ki}}$ に対するメンバシップ関数の出力值 $\mathrm{m}_{\mathrm{ki}}\left(\mathrm{u}_{\mathrm{i}}\right)$ を計算する. 各 人力に対してこれらの計算をし代数値積を求め, さらにル 一ル $\mathrm{k}$ の貢献度 $\mathrm{c}_{\mathrm{k}}$ を掛けあわせたものをルール $\mathrm{k}$ の適用度 $\mathrm{mm}_{\mathrm{k}}$ と㭔び，次のように計算する.

$$
m m_{k}=\left(\prod_{i=1}^{p} m_{k i}\left(u_{i}\right)\right) \cdot c_{k}
$$

ルール $\mathrm{k}$ における出力 $\mathrm{j}$ の望ましい值が $\mathrm{z}_{\mathrm{kj}}$ であるとき， これらを各ルールの適用度を用いて内挿し出力

を求める.

$$
y_{j}=\frac{\sum_{k=1}^{N} m m_{k} z_{k j}}{\sum_{n=1}^{N} m m_{n}}
$$

\section{2 前件部の種類}

本研究で作成した知能部の前件部には，ロボット座標系 における以下の 7 種類の情報を用いた.
(1)ボールの距離
(5)味方ゴールの距離
(2)ボールの方位
(6)昧方ゴールの方位
(3)敵ゴールの距離
(7) 8 方向の黒色の割合

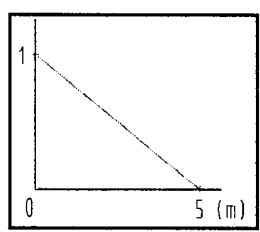

$\mathrm{Ne}$ (Near)

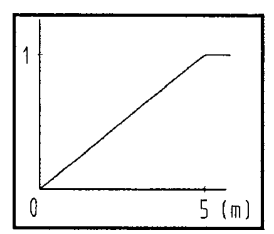

Fa(Far)

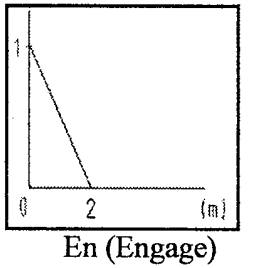

En

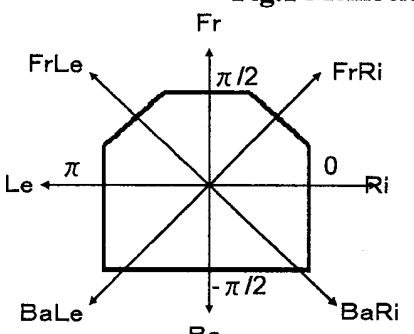

Fig.2 8 Direction Fig.3 Membership Function (direction)

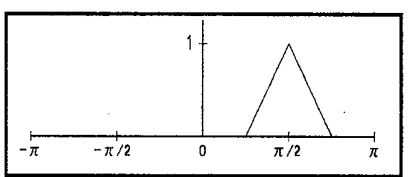

Fr(Front)

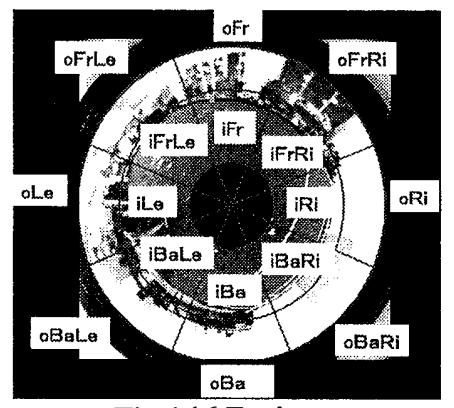

Fig.416 Territorys
Fig.5 Robot coordinate system

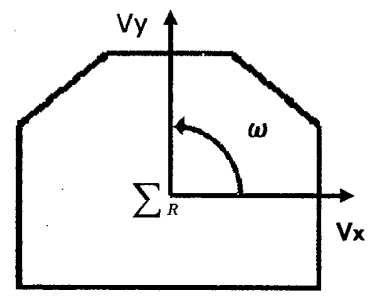

\section{3 メンバシップ関数}

ファジィ制御に必要なメンバシップ関数の作成にあたり， 前件部で扱う距離は現在のカメラの視認限界の0〜 $5 \mathrm{~m}$ で あるとして，Fig.1 に示す $\mathrm{Ne}, \mathrm{Fa}, \mathrm{En} の 3$ 種類のメンバシ ップ関数を作成した。

また，前件部における方位には，Fig.2 に示す 8 方位に関

して, Fig.3のようなメンバシップ関数を作成した.

その他に，フィールド上の敵ロボットを検知し回避行動 を行わせることを目的として，全方位力メラから得られる 画像を Fig.4のように 8 方向・16 領域に分割し，それぞれ の領域における黒色の割合をメンバシップ関数と同等の役 割を果たすように 0〜1の值に正規化して, 前件部の出力值 に用いた。

\section{4 後件部の種類}

後件部の出力は Fig.5に示すようにロボット座標系 $\Sigma_{R}$ に おける $\mathrm{X}, \mathrm{Y}$ 方向の速度 $\mathrm{Vx} \cdot \mathrm{Vy}(\mathrm{m} / \mathrm{s})$ と角速度 $\omega(\mathrm{rad} / \mathrm{s})$ とした。 2.5 貢献度

フリーキックや他ロボットの接触時などへの対処は明ら かに異なるルール群での処理が必要になるため，単純なリ ニアファジィ推論法のみでは対応できない. 貢献度 $\mathrm{c}_{\mathrm{k}}$ は本 
来ルールごとの重み付けを行うための值であるが, 本研究 では If-Then 機能を一部融合する目的で, コマンドに対し て1または0の值を設定するように貢献度を利用している。 2.6 ファジィルール

7 つの前件部と, 3 つの後件部を使い, 下記の 17 個のル ールを作成した。

No.1ボールに近ふく

No.2ト゚リフル

№.3回り込み(ボールが直後ろ)

No.4回り込み(ボールが右)

№.5: 回り远み(ボールが左)

No.6: 回り込み(ボールが後方)

No.7: 䑤ゴールに近づきすぎ防止

No.8:味方ジールに近つきすぎ防止

No.9:ボールを見失った契合味方ゴールに展る

\section{3. シミュレータを用いた検証}

ボールをゴールまで運ぶことを基本的な機能と考え, 2.6 節で述ベたルールの内, No1〜14 のルールを用い, Fig. 6 の（a）に示すような初期位置を与え，ロボットとボールを 停止させた状態からシミュレーションを行い, 知能部の基 本的な機能の検証を行った.

シミュレーションを開始すると，ロボットは（b）に示す ような進路をとり，ボールをゴールに運ぶことができた. このことから，ファジィ制御を用いて基本的な動作をロボ ットに実現させることができたと考えられる。

\section{4. ルール追加の際の手法の提案}

\section{1 ルール追加のための手順}

ロボットに障害物を回避させる行動をさせることを目的 として, 2.6 節で述べたルールの内, No. 15〜17 のルールを 新たに追加した. 今回追加したルールの一例を口頭表現で 示すと以下のようになる。

・No. 16:ボールが前方かつ至近距離にあり，障害物が左 前方に存在した場合，右方向へ移動する.

・No. 17：ボールが前方かつ至近距離にあり，障害物が前 方に存在した場合，左方向一回転する.

このようなルールを追加する際に, 次の 2 条件を, 満た すことを確認作業とする.

$\mathbf{A}$ ：目的とするロボットの動作を達成する.

B : 追加したルールが機能しない状況において, 追加し た前後での動作に差異が発生しない.

\section{2 障害物の回避動作の達成}

まず，条件 Aについて考え， No1〜17 のルールを用い， Fig.7 の (a)に示すような初期条件を与えた.このとき敵の ロボットはその位置から移動しないものとしてシミュレー ションを行ったところ, ロボットは(b)に示すような進路を とり，障害物である敵のロボットを回避した。

また, Fig.8 は敵ロボットの設置がない場合, Fig.9 は敵 ロボットの設置がある場合の, ルール 16.17 における出力 $\mathrm{j}$ に重みをかけた值

$$
o_{k j}=\frac{m m_{k} z_{k j}}{\sum_{n=1}^{N} m m_{n}} \quad(k=16,17)
$$

をグラフに表したものである.

Fig.8ではグラフに值が全く検出されないのに対し, Fig.9 では敵のロボットが近づいたときに，どのルールから出力

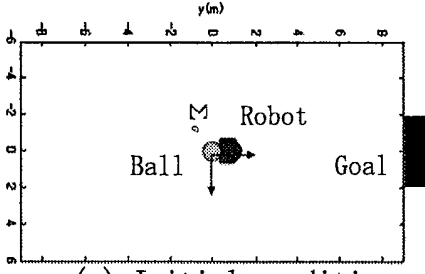

(a) Initial condition

(a) Initial condition Fig. 7 The
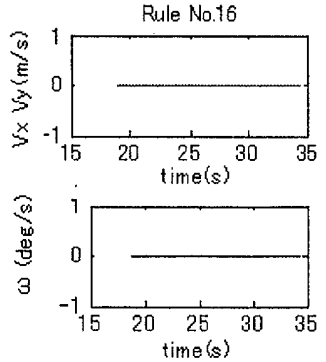

Fig. 8 Weighted output $j$ on rule 16\&17 (No Enemy)
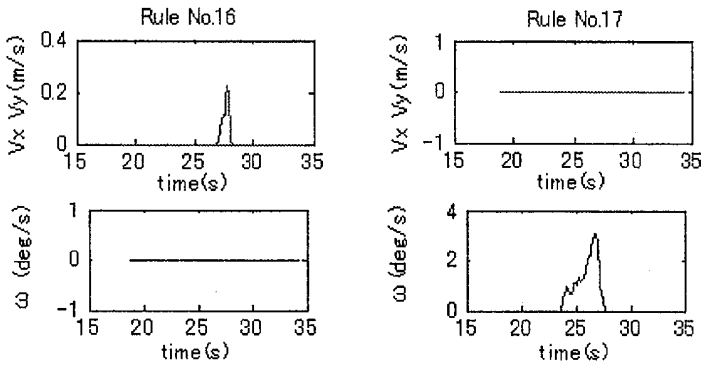

Fig. 9 Weighted output $j$ on rule 16\&17 (With Enemy)

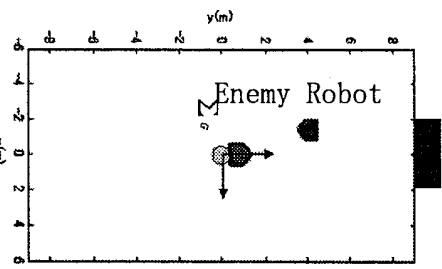
的とするロボットの動作に貢献していることの評価を容易 に行うことができる。

\section{3 ルール追加前後での動作の差異}

次に条件Bについても，ルールを追加する前後において ロボットの進路と， $\mathrm{o}_{\mathrm{ki}}(k \neq 16,17)$ のグラフを比較したが 差異はほぼ見て取れなかった。このことから条件 Bを満た したと考えられる。

\section{5. まとめ}

本研究では，ファジィ理論を用いた知能部を開発し，新 たにファジィルールを追加する際の機能の確認手順の確立 を目指した．その結果，2つの条件に注意してルールを作 成することで，新たな機能を追加できることを確認した．

しかし，経験則に左右されがちなルールの作成手順を， 如何に容易に示すことができるかが，今後の課題である。

\section{参考文献}

[1] RoboCup Official Homepage: http://www.robocup.or.jp/ [2] 津崎亮一，吉田和夫：“ファジィポテンシャル法に基づ く全方位四角を用いた自律移動ロボットの行動制御”, 日本ロボット学会誌, Vol.21, no.6, pp.76-82, 2003 